\title{
Health and re-employment in a two year follow up of long term unemployed
}

\author{
Bjørgulf Claussen, Arild Bjørndal, Peter F Hjort
}

\begin{abstract}
Study objective-The aim was to examine re-employment and changes in health during a two year follow up of a representative sample of long term unemployed.

Design-This was a cross sectional study and a two year follow up. Health was measured by psychometric testing, Hopkins symptom checklist, General health questionnaire, and medical examination. Health related selection to continuous unemployment and recovery by re-employment was estimated by logistic regression with covariances deduced from the labour market theories of human capital and segmented labour market.
\end{abstract}

Setting-Four municipalities in Grenland, southern Norway.

Subjects-Participants were a random sample of 17 to 63 year old people registered as unemployed for more than 12 weeks.

Main results-In the cross sectional study, the prevalence of depression, anxiety, and somatic illness was from four to 10 times higher than in a control group of employed people. In the follow up study, there was considerable health related selection to reemployment. A psychiatric diagnosis was associated with a $70 \%$ reduction in chances of obtaining a job. Normal performance on psychometric testing showed a two to three times increased chance of re-employment. Recovery of health following re-employment was less than expected from previous studies.

Conclusions-Health related selection to long term unemployment seems to explain a substantial part of the excess mental morbidity among unemployed people. An increased proportion of the long term unemployed will be vocationally handicapped as years pass, putting a heavy burden on social services.

National Institute of Public Health, Unit for Health Services Research, Oslo, Norway

B Claussen

A Bjørndal

P F Hjort

Correspondence to: Dr Claussen, at: University of Oslo, Department of Community Medicine, Unit of Social Insurance Medicine, PO Box 95 Ulleval Sykehus, N-0407 Oslo, Norway

Accepted for publication July 1992 f Epidemiol Community Health 1993; 47: 14-18

Increasing unemployment is a challenge to the health service in most Western countries. Excess morbidity and mortality among unemployed are well documented, ${ }^{12}$ although we do not know much about the explanation.

There is growing evidence for the view that unemployment damages health, ${ }^{3}$ even if some researchers doubt that lack of paid work per se can cause sickness. ${ }^{4}$ Another explanation is that bad health predisposes to unemployment, either by job loss $\left(S_{1}\right.$ in the figure) or by selection to re-employment ( $S_{2}$ in the figure).
Selection has been less investigated than the causal hypothesis ${ }^{6}$ and is not found in most investigations. ${ }^{78}$ Even so many researchers find it probable that health related selection explains some of the excess morbidity among the unemployed. ${ }^{1}$ If this factor is large, it should have implications for the social and health services. Handicapped job seekers will constitute an increasing proportion of the long term unemployed, as they are repeatedly scrutinised by personnel mangers over the years. Caring for them will be a challenge of increasing significance.

We studied health and re-employment in a two year follow up of a representative sample of long term unemployed in Norway. Our aims were primarily to assess the selection to re-employment on account of mental distress and of medical diagnoses. It is scarcely possible to measure $S_{1}$ in the figure, because that would demand baseline health data for huge numbers of employees before any redundancies are known. ${ }^{6}$ We think, however, that $S_{2}$ (selection to continuous unemployment) is more important on today's labour market. The reason is that redundancies have reached a massive scale, while the exit gate from unemployment is narrow and well guarded by personnel managers.

Secondly, we wanted to determine recovery from mental distress following re-employment, which may indicate a causal relationship between job loss and mental health. Again the measure is indirect. $C_{1}$ in the figure would be the real causal relationship, but this proportion cannot be entangled from $S_{2}$ without baseline data.

\section{Methods}

The study was carried out in the four municipalities of Grenland, a relatively urban district of Norway, partly because the district resembles the country, but also because one of the authors had been a general practitioner there for 10 years. Thirty two per cent of the 92940 inhabitants are workers, compared to $24 \%$ in Norway as a whole. Otherwise the differences in the labour market structure are small. ${ }^{9}$ The unemployment rate in the area increased from $2.6 \%$ when the study started during the spring of 1988 to $5 \cdot 1 \%$ in the autumn of 1990 , which was near the national levels of 2.0 and $4.8 \%$ respectively.

A random sample of a quarter of those registered unemployed for more than 12 weeks was offered a health examination, except the "early pensioners" over 63 years. For practical reasons, we defined the unemployed as those registered at the labour market authorities. This gives a relatively healthy sample, because a pre- 


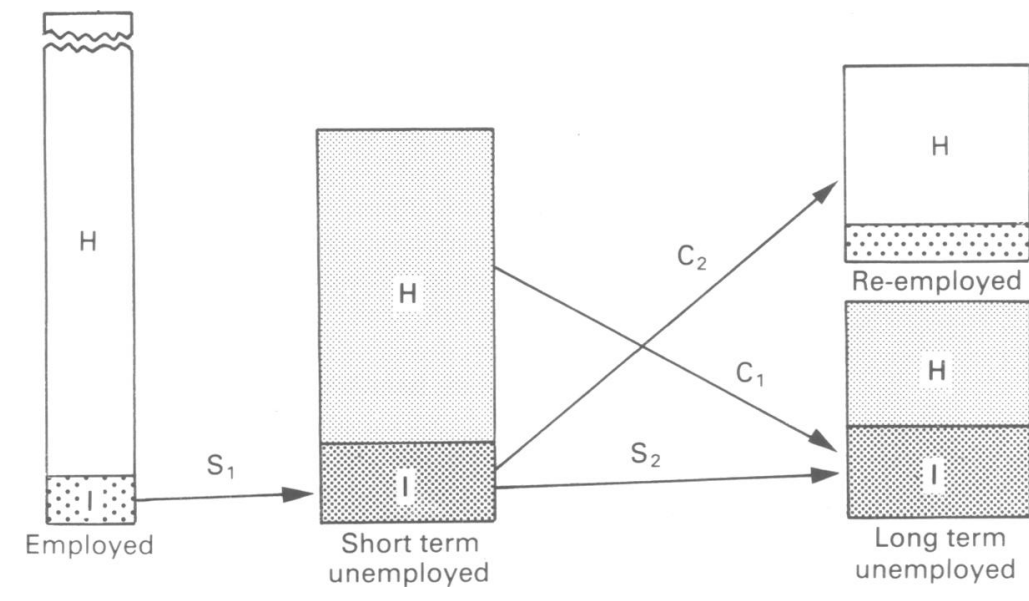

$A$ model of health related selection to unemployment and of unemployment as a cause of ill health. $H=$ healthy; $I=i l l ; S_{1}=$ selection to job loss; $S_{2}=$ selection to continuous unemployment; $C_{1}=$ healthy unemployed become ill as a consequence of long term unemployment; $C_{2}=$ sick unemployed who improve after re-employment.

condition for registering is the ability to take whatever job is offered. A limit of 12 weeks' duration was set in order to avoid the less health related "frictional unemployment".

Three hundred and ten persons attended for the first examination in $1988,83 \%$ of the sample.

Table I Background characteristics (percentage or means) of the study group, all Norwegian registered unemployed, ${ }^{11}$ all employed from Grenland, 9 and a representative sample of the occupational population in Norway ${ }^{13}$

\begin{tabular}{|c|c|c|c|c|}
\hline & \multicolumn{2}{|l|}{ Unemployed } & \multicolumn{2}{|l|}{ Employed } \\
\hline & $\begin{array}{l}\text { Grenland } \\
\text { study group } \\
1988 \\
(n=310) \\
\end{array}$ & $\begin{array}{l}\text { All } \\
\text { Norwegian } \\
\text { unemployed } \\
(n=56633)\end{array}$ & $\begin{array}{l}\text { Grenland } \\
\text { census } \\
1980^{a} \\
(n=41841)\end{array}$ & $\begin{array}{l}\text { National } \\
\text { sample } \\
1987^{a} \\
(n=2638)\end{array}$ \\
\hline $\begin{array}{l}\text { Age (years) } \\
16-19 \\
20-29 \\
30-49 \\
50-63 \\
64-70\end{array}$ & $\begin{array}{r}6 \\
46 \\
37 \\
12 \\
-\end{array}$ & $\begin{array}{r}11 \\
42 \\
33 \\
8 \\
7\end{array}$ & $\begin{array}{r}9 \\
25 \\
42 \\
24 \\
-\end{array}$ & $\begin{array}{r}8 \\
26 \\
33 \\
20 \\
-\end{array}$ \\
\hline Gender $(\%$ female $)$ & 42 & 40 & 40 & 47 \\
\hline $\begin{array}{l}\text { Weeks registered } \\
0-12 \\
13-26 \\
27-52 \\
53-80 \\
81-\end{array}$ & $\begin{array}{r}- \\
52 \\
32 \\
11 \\
5\end{array}$ & $\begin{array}{r}61 \\
15 \\
16 \\
5 \\
3\end{array}$ & $\begin{array}{l}- \\
- \\
- \\
-\end{array}$ & $\begin{array}{l}- \\
- \\
- \\
-\end{array}$ \\
\hline $\begin{array}{l}\text { Occupation (previous) } \\
\text { Professional, technical } \\
\text { Administrative } \\
\text { Clerical } \\
\text { Sales } \\
\text { Farmers, fishermen } \\
\text { Transport, communication } \\
\text { Labourers } \\
\text { Service } \\
\text { Unknown }\end{array}$ & $\begin{array}{r}12 \\
2 \\
8 \\
10 \\
1 \\
8 \\
43 \\
16 \\
-\end{array}$ & $\begin{array}{r}11 \\
1 \\
8 \\
10 \\
2 \\
7 \\
38 \\
12 \\
9\end{array}$ & $\begin{array}{r}21 \\
5 \\
9 \\
9 \\
2 \\
7 \\
33 \\
11 \\
3\end{array}$ & $\begin{array}{r}24 \\
5 \\
12 \\
10 \\
5 \\
8 \\
22 \\
13 \\
2\end{array}$ \\
\hline $\begin{array}{l}\text { Socioeconomic status } \\
\text { Unskilled workers } \\
\text { Skilled workers } \\
\text { Salaried employees low level } \\
\text { Salaried employees medium level } \\
\text { Salaried employees high level } \\
\text { Self employed and liberal } \\
\text { professions } \\
\text { Agriculture and fishery } \\
\text { Others }\end{array}$ & $\begin{array}{r}43 \\
9 \\
23 \\
22 \\
1 \\
1 \\
- \\
-2\end{array}$ & $\begin{array}{l}\overline{-} \\
\overline{-} \\
\overline{-} \\
\overline{-} \\
-\end{array}$ & $\begin{array}{r}26 \\
12 \\
16 \\
20 \\
7 \\
\\
1 \\
4 \\
14\end{array}$ & $\begin{array}{r}18 \\
9 \\
18 \\
29 \\
9 \\
\\
3 \\
7 \\
7\end{array}$ \\
\hline $\begin{array}{l}\text { Social network (index) } \\
\text { Low } \\
\text { Medium } \\
\text { High }\end{array}$ & $\begin{array}{l}38 \\
44 \\
19\end{array}$ & $\begin{array}{l}- \\
-\end{array}$ & $\begin{array}{l}- \\
-\end{array}$ & $\begin{array}{l}33 \\
38 \\
29\end{array}$ \\
\hline $\begin{array}{l}\text { Social support (index) } \\
\text { Low } \\
\text { Medium } \\
\text { High }\end{array}$ & $\begin{array}{l}12 \\
61 \\
27\end{array}$ & $\begin{array}{l}- \\
\overline{-}\end{array}$ & $\begin{array}{l}- \\
-\end{array}$ & $\begin{array}{l}15 \\
60 \\
25\end{array}$ \\
\hline Education (average years) & $10 \cdot 3$ & - & $10 \cdot 6$ & $10 \cdot 8$ \\
\hline $\begin{array}{l}\text { Net household monthly income per } \\
\text { capita (average } f \text { ) }\end{array}$ & 318 & - & 360 & 368 \\
\hline
\end{tabular}

${ }^{a}$ Age standardised after the study group, except for the first two variables
They were representative of the population and of all registered unemployed in Norway with respect to the available variables in table $\mathrm{I}$. The results may be generalised to all Norwegian registered long term unemployed people. ${ }^{10}$ A new examination two years later was attended by 291 of them, giving an overall participation rate of $78^{\circ}{ }_{0}$. Two hundred and seventy seven answered the tests twice and this is the total number in most of the tables. They did not differ from the original sample in gender $(p=0.354)$, age $(p=0.439)$, or municipality $(p=0 \cdot 304)$.

The examination consisted of a structured interview by a nurse, pen and paper tests, and the doctor's diagnoses and advice. In order to establish a reference group of unemployed people, crucial questions were taken from national surveys. Sociodemographic variables from the last census gave data comparable with all people employed in Grenland. ${ }^{9}$ More detailed information was obtained with variables from the Health Survey $1985^{12}$ and the Level of Living Survey 1987. ${ }^{13}$

The index for social network was constructed from six questions about parents, spouse, children, friends, and frequencies of visits; the index for social support was derived from two questions about expectations of financial and practical help when needed. ${ }^{10}$ Socioeconomic status was determined from a seven step index based on occupation. ${ }^{13}$

The Hopkins symptom checklist is a 30 item version of the psychometric test SCL- $90 .{ }^{14}$ It was constructed for the Health Survey 1985 and is the only test with a satisfactory Norwegian reference population of employed people. ${ }^{12}$ A similar version is also used in unemployment research. ${ }^{8}$ The three subscales in table III are quite like the corresponding ones in the much used 58 item version. ${ }^{14}$ Here, the cutoff point for psychiatric morbidity is $\geqslant 1.75$ per item, which is commonly used because it gave prevalences of $2.5^{\circ}{ }_{0}$ in an American household survey.

The General health questionnaire (GHQ) is much used for measuring psychological distress, ${ }^{15}$ and has been applied to the unemployed. $^{716-18}$ We used Likert scoring as a continuous measurement and a cutoff point $\geqslant 5$ in the GHQ scoring for "case finding" with this 28 item version.

The somatic diagnoses in table II required a medical condition that gives an enduring and significant reduction of the common level of functioning. Psychiatric syndromes were diagnosed after the criteria in the Diagnostic and statistical manual of mental disorders (DSM-III) axis I, and personality disorders after axis II.

When examining re-employment in relation to health, we assumed that the most important confounding variables could be deduced from the theories of human capital (education, years in paid work, and duration of the longest lasting job) and of segmented labour market (gender, socioeconomic status, and social network). ${ }^{19}$ Another aspect of labour market conduct is personal involvement in paid work, which was measured by the Employment commitment test. ${ }^{20}$

The hypotheses were tested by $\chi^{2}$ for categorical variables and two tailed $t$ tests for comparisons of means. Logistic and multiple linear regressions 
Table II Average scores per item (95\% confidence intervals) for psychometric tests at the health examinations in 1988 and 1990

\begin{tabular}{|c|c|c|c|c|}
\hline \multirow[b]{2}{*}{$\begin{array}{l}\text { Test } \\
\text { scales }\end{array}$} & \multicolumn{2}{|l|}{1988} & \multicolumn{2}{|l|}{1990} \\
\hline & $\begin{array}{l}\text { Unemployed } \\
(n=298)\end{array}$ & $\begin{array}{l}\text { Employed } \\
(n=4924)\end{array}$ & $\begin{array}{l}\text { Unemployed } \\
(n=164)\end{array}$ & $\begin{array}{l}\text { Re-employed } \\
(n=113)\end{array}$ \\
\hline $\begin{array}{l}\text { Hopkins symptom checklist } \\
\text { Somatic symptoms }\end{array}$ & 1.41 & $1 \cdot 19$ & & \\
\hline Anxiety & & $1 \cdot 13$ & $\begin{array}{l}1 \cdot 40-1 \cdot 4 \\
1 \cdot 43\end{array}$ & $\begin{array}{l}(1.30-1 \cdot 44) \\
1 \cdot 30\end{array}$ \\
\hline Depression & $\begin{array}{l}(1.35-1.45) \\
1.47 \\
(1.41-1.53)\end{array}$ & $\begin{array}{l}(1 \cdot 12-1 \cdot 15) \\
1 \cdot 08 \\
(1 \cdot 05-1 \cdot 13)\end{array}$ & $\begin{array}{l}(1.37-1.49) \\
1.47 \\
(1.41-1.53)\end{array}$ & $\begin{array}{l}(1 \cdot 26-1 \cdot 34) \\
1.30 \\
(1 \cdot 26-1 \cdot 34)\end{array}$ \\
\hline General health questionnaire & $\begin{array}{l}0.88 \\
(0.82-0.94)\end{array}$ & - & $\begin{array}{l}0.82 \\
(0.76-0.88)\end{array}$ & $\begin{array}{l}0.69 \\
(0.65-0.73)\end{array}$ \\
\hline
\end{tabular}

${ }^{a} \mathrm{~A}$ household health survey, age standardised after the study group ${ }^{12}$

were carried out by SPSS-PC. ${ }^{21}$ Covariates were the seven variables mentioned above.

\section{Results}

THE CROSS SECTIONAL EXAMINATION

Table I shows that the study group was relatively young, while the sex ratio was the same as among the employed. The rest of the tables are therefore age standardised after the study group.

The unemployed had fewer resources like household income $(p<0.001)$, socioeconomic status $(\mathrm{p}<0.001)$, and education $(\mathrm{p}=<0.01)$ than employed people in the Grenland area. Social network was poorer than in the national sample of employed $(p<0.001)$, social support about the same $(p=0 \cdot 223)$

The study group scored much higher on the Hopkins symptom checklist than the reference group (table II). The prevalences of mental disorders were four to ten times higher (table III). These differences were the same for both genders

Table III Prevalences of sickness (percentage) after dichotomous health measurements at the health examinations in 1988 and 1990

\begin{tabular}{lllll}
\hline $\begin{array}{l}\text { Health } \\
\text { measurement }\end{array}$ & $\begin{array}{l}1988 \\
\begin{array}{l}\text { Unemployed } \\
(n=298)\end{array}\end{array}$ & $\begin{array}{l}\text { Employed } \\
(n=4924)\end{array}$ & $\begin{array}{l}1990 \\
\text { Unemployed } \\
(n=164)\end{array}$ & $\begin{array}{l}\text { Re-employed } \\
(n=113)\end{array}$ \\
\hline $\begin{array}{lllll}\text { Psychometric tests } \\
\quad \text { Hopkins symptom checklist }\end{array}$ & 17 & $4 \ddagger$ & 18 & 13 \\
$\quad$ Somatic symptoms & 17 & $2 \ddagger$ & 20 & 12 \\
$\quad$ Anxiety & 22 & $2 \ddagger$ & 25 & $13^{\star}$ \\
$\quad$ Depression & 36 & - & 34 & 28 \\
$\quad$ General health questionnaire & & & & \\
Doctor's diagnoses & 26 & - & 34 & $23^{\star}$ \\
$\quad$ Somatic disease & 29 & - & 41 & $16 \dagger$ \\
$\quad$ Psychiatric syndrome & 10 & - & 13 & $3 \ddagger$ \\
$\quad$ Personality disorder & & & & \\
\hline
\end{tabular}

and did not depend on socioeconomic status, household income, social network, or reported alcohol consumption, as described elsewhere. ${ }^{10}$

HEALTH RELATED SELECTION TO RE-EMPLOYMENT Forty one percent were re-employed within two years (table IV). The differences in education, socioeconomic status, and social network show

Table IV Sociodemographic characteristics in 1988 after employment status in 1990

\begin{tabular}{lcc} 
Table IV Sociodemographic characteristics in 1988 after & employment status in 1990 \\
\hline & $\begin{array}{c}\text { Re-employed } \\
(n=118)\end{array}$ & $\begin{array}{c}\text { Unemployed } \\
(n=173)\end{array}$ \\
\hline Gender (females, \%) & 45 & 43 \\
Age (average years) & $32 \cdot 1$ & $34 \cdot 3$ \\
Socioeconomic status (average index score) & $2 \cdot 46$ & $2 \cdot 17^{\star}$ \\
Education (average years) & $10 \cdot 6$ & $10 \cdot 1^{\star}$ \\
Net household income per capita (average $£$ ) & 308 & 331 \\
Social network (average index score) & $10 \cdot 5$ & $9 \cdot 6 \star$ \\
Social support (average index score) & $2 \cdot 38$ & $2 \cdot 36$ \\
Employment commitment test (average score) & $4 \cdot 31$ & $4 \cdot 26$ \\
Time in paid work (average months) & 130 & 155 \\
Longest lasting job (average months) & $64 \cdot 5$ & $87 \cdot 9 \star$ \\
\hline " & &
\end{tabular}

${ }^{\star} \mathrm{p}<0.05$ by $t$ test that the more resourceful unemployed had better chances of getting a job when education, socioeconomic status, and social network are recognised as resources. Gender and the Employment commitment test were not bivariately connected with continuous unemployment. The differences in time of longest employment and in any paid work disappeared after controlling for age and socioeconomic status.

Selection to re-employment was estimated by logistic regression with dichotomised health measures as predictors (table $\mathrm{V}$ ). The anxiety scale, the General health questionnaire, and the psychiatric diagnoses from the first examination showed a significant effect on re-employment. The chances for getting a job were reduced to $24-47 \%$ for the sick unemployed compared to the healthy unemployed. Continuous scores in multiple linear regression gave the same level of significance for all the test scales.

In the logistic regressions, variables other than health had no significant effect on continuous unemployment (gender, education, time in paid work, socioeconomic status, social network, or the Employment commitment test).

\section{RECOVERY AFTER RE-EMPLOYMENT}

Table VI shows the probability of scoring as sick in the follow up controlled by baseline health status, making the logistic equation a measure of the change in relative risks of scoring as sick in the two groups. The prevalence of mental disorders was reduced by getting a job. However, only the depression subscale showed significant differences. The re-employed were $45 \%$ as likely to experience depression as people who were still unemployed. The continuous measures gave the same levels of significance in multiple linear regression, except for a significant recovery in the General health questionnaire $(p=0.03)$.

\section{Discussion}

Do these figures reflect real health? The main instruments are two psychometric tests, which are much used and well validated as measures of mental disorders. ${ }^{1415}$ The doctor's diagnoses, on the other hand, are subject to the low reliability of clinical judgements and must be taken for what they are The actual result of selection to re-employment, however, supports the measurements, because health is an integrated part of the well established human capital theory of labour market conduct. ${ }^{19}$

CROSS SECTIONAL RESULTS

Psychiatric disorders are far more common among the long term unemployed than in the working population, even in affluent Norway. This contradicts the view that poverty following lack of work is the main explanation of excess morbidity among the unemployed. ${ }^{5}$ We found that, as shown before, ${ }^{71718}$ relatively well situated groups of Scandinavian unemployed people experience the same high degree of mental distress as their counterparts in the $\mathrm{UK}^{16}$ and USA. ${ }^{8}$ Thus the model in the figure for explaining excess morbidity is relevant for Norwegian unemployed.

SELECTION

We found a noteworthy selection to re-employment, both in terms of mental distress and of 
Table $V$ Selection to re-employment: results from logistic regression with the probability of re-employment in 1990 as dependent variable and health measures in 1988 as predictors, together with gender, socioeconomic status, social network, education, years in paid work, duration of the longest lasting job, and the Employment commitment test as covariates

\begin{tabular}{llll}
\hline & $\begin{array}{l}\text { Regression } \\
\text { coefficient }(B)\end{array}$ & $\underline{1}_{a}$ \\
Predictor $(0=$ healthy, $1=$ sick) & & & \\
\hline Psychometric tests & & & \\
$\quad$ Hopkins symptom checklist & 0.14 & 0.69 & 0.87 \\
$\quad$ Somatic symptoms & 1.01 & 0.01 & 0.36 \\
$\quad$ Anxiety & 0.21 & 0.52 & 0.81 \\
$\quad$ Depression & 0.76 & 0.01 & 0.47 \\
General health questionnaire & & & \\
Doctor's diagnoses & 0.51 & 0.08 & 0.60 \\
Somatic disease & 1.20 & $<0.001$ & 0.30 \\
Psychiatric syndrome & 1.43 & 0.01 & 0.24 \\
Personality disorder & & & \\
\hline
\end{tabular}

${ }^{a}$ The odds ratio for being re-employed in 1990 for the sick unemployed in 1988 compared to the healthy unemployed. Those scoring as anxious had for example a $36 \%$ chance of re-employment compared to the non-anxious, given the same age, education, etc

Table VI Recovery by re-employment: results from logistic regression with the probability of being sick in 1990 as dependent variable and employment status in 1990 as predictor, controlled for the same health measure in 1988 and the covariates from table $V$

\begin{tabular}{llll}
\hline Dependent variable & $\begin{array}{l}\text { Regression } \\
\text { coefficient }\end{array}$ & $\frac{1}{a}_{a}$ \\
\hline Hopkins symptom checklist & & & ${ }_{e}^{B}$ \\
Somatic symptoms & 0.65 & 0.14 & 0.52 \\
Anxiety & 0.08 & 0.86 & 0.93 \\
Depression & 0.80 & 0.04 & 0.45 \\
General health questionnaire & 0.22 & 0.45 & 0.80 \\
\hline
\end{tabular}

${ }^{a}$ The change from 1988 to 1990 in relative risk for being sick for re-employed compared to still unemployed. Getting a job reduces the chance for scoring as depressed to $45^{\circ}{ }_{0}$ of the chance for those still going unemployed

medical diagnoses. Sick unemployed people in 1988 had between a quarter and a half of the probability for re-employment in 1990 as the healthy ones. The selection was mostly due to psychiatric illness, while the somatic medical diagnoses showed a low selection effect.

Surprisingly, human capital variables other than health did not predict re-employment in our sample—not even education or work experience. This probably means that personnel managers are looking for more subtle traits than we were able to measure. Neither did we find the sex differences in unemployment distress that are shown in many European countries. ${ }^{1}$ Employed women in Norway seem to be as much devoted to paid work as men

Selection to re-employment was not found in studies from Michigan, ${ }^{8}$ Finland, ${ }^{7}$ and the United Kingdom, ${ }^{16}$ the first of these using the Hopkins symptom checklist, the other two the General health questionnaire. The explanation is probably that they interviewed other groups living under different labour market conditions than our sample. The three samples consisted of blue collar job seekers in the 20 to 50 year age range with unemployment of any duration, while ours was a representative one of long term unemployed people aged 17 to 63 years. The British and the Finnish samples were followed in a stable labour market, the US sample during an upgoing business cycle. The three countries had higher unemployment rates than Norway, but none of them were increasing so rapidly. From the time we started our study in 1988 until today, the unemployment rate has gone up from $2 \%$ to a continental level of nearly $8 \% .{ }^{11}$ Our sample was probably more heavily selected than the others.

\section{RECOVERY}

If excess mental distress disappears on reemployment, this indicates that causation is the dominating explanation. Again, lack of baseline health data renders exact calculations impossible, because we cannot be sure that recovery is complete for all re-employed people.

Recovery was moderate in our study, in contrast to the nearly complete recovery in the three other investigations. ${ }^{7816}$ Again the explanation may be sample differences. Psychometric scores increase most in the first three months of unemployment and then tend to go down. ${ }^{716}$ This leads to bigger differences between unemployed and re-employed people in the other three samples with a large proportion of short term unemployed. Conditions on the labour market may also be important. Many of our re-employed people entered jobs with less security than before, which may explain the low recovery rate. The seven item socioeconomic status index is a crude measure for social mobility, but here $36 \%$ of the re-employed crept downwards and $18 \%$ upwards.

\section{IMPLICATIONS FOR THE HEALTH SERVICE}

Our findings raise the question of what society should do with a growing population of unhealthy and unsuccessful job seekers. Over many years of low unemployment, Social Insurance in Norway has granted a great number of disability pensions. This practice is now under attack, partly because of the sickness inducing effect of a disability pension, ${ }^{22}$ and partly because of expenditure on a growing number of pensioners. Both are serious problems that need attention. Society must in some way take care of the most unhappy participants in the labour market, and reforms should not strike at the weakest.

This is important also from a preventive view. Sick unemployed people are especially predisposed to further deterioration. ${ }^{1}$ Preventive measures for people who are unemployed in the long term because of poor health should have priority. Vocational rehabilitation, occupational programmes, and sheltered employment are important, as long as our societies do not provide primary prevention in this field, ie, paid work for all.

This study was supported by the Norwegian Research Council for Science and the Humanities and by the County Labour Authority of Telemark.

1 Smith R. Unemployment and health. A disaster and a challenge. Oxford: Oxford University Press, 1987.

2 Martikainen PT. Unemployment and mortality among Finnish men, 1981-85. BMF 1990; 301: 407-11.

3 Smith R. Unemployment: here we go again. BMf 1991; 302 : 606-7.

4 Kagan AR. Unemployment causes ill health: the wrong track. Soc Sci Med 1987; 25: 217-8.

5 Bartley $M$. Unemployment and health: selection or causation-a false antithesis? Sociol Health Illness 1988; 10: $41-67$.

6 Morris JK, Cook DG. A critical review of the effect of factory closures on health. $\mathrm{Br} \mathcal{F}$ Ind Med 1991; 48: 1-8.

7 Lahelma E. Unemployment, re-employment and mental well-being. A panel survey of industrial jobseekers in Finland. Scand F Soc Med 1989; suppl 43.

8 Kessler RC, Turner JB, House JS. Unemployment, reemployment and emotional functioning in a community sample. Am Sociol Rev 1989; 54: 648-57.

9 Central Bureau of Statistics. Population and housing census 1980. Kongsvinger: Central Bureau of Statistics, 1982.

10 Claussen B. Arbeidslos og helselos? En medisinsk undersokelse av lengre tids arbeidslose fra Grenland 1988. Oslo: Report no 2/1991, Unit for Health Services Research, National Institute of Public Health. (English summary)

11 Directorate of Labour. Labour Market Statistics no 10/1988 and 10/1992. Oslo: Directorate of Labour, 1988 and 1991. 2 Central Bureau of Statistics. Health survey 1985 . Oslo: Central Bureau of Statistics, 1987.

13 Central Bureau of Statistics. Level of living survey 1987 Oslo: Central Bureau of Statistics, 1988. 
14 Derogatis LR, Lipman RS, Rickels KL, Uhlenhuth EH, Covi L. The Hopkins Symptom Checklist (HSCL): a measure of primary symptom dimensions. In: Pichot D, ed. Psychological measurem
Karger Verlag, 1974.

15 Goldberg D, Williams P. A user's guide to the General health questionnaire. Winsor: NEFR-Nelson Publishing Company, 1988.

16 Warr P, Jackson P. Factors influencing the psychological impact of prolonged unemployment and of re-employment. Psychol Med 1985; 15: 795-807.

17 Iversen L, Sabroe S. Psychological well-being among unemployed and employed people after a company closedown: a longitudinal study. F Soc Issues 1988; 44: 141-52.
18 Brenner SO, Levi L. Long-term unemployment among women in Sweden. Soc Sci Med 1987; 25: 153-61.

19 Fallon P, Verry D. The economics of labour markets. Oxford: Philips Allan Publisher Limited, 1988.

20 Warr P, Cook J, Wall T. Scales for the measurement of some work attitudes and aspects of psychological well-being. $f$ Occup Psychol 1979; 52: 129-48.

21 Norusis MJ. SPSS/PC for the IBM PC. Chicago: SPSS Inc., 1986

22 Westin $S$. The structure of a factory closure: individual responses to job-loss and unemployment in a 10-year controlled follow-up study. Soc Sci Med 1990; 31: 1301-11. 